\title{
The Right to Education for the Retarded
}

Jan Sheldon

James A. Sherman

University of Kansas

\section{Introduction}

Today, education is perhaps the most important function of state and local governments. Compulsory school attendance laws and the great expenditures for education both demonstrate our recognition of the importance of education to our democratic society. It is required in the performance of our most basic public responsibilities, even service in armed forces. It is the very foundation of good citizenship. Today, it is a principle instrument in awakening the child to cultural values, in preparing him for later professional training, and in helping him to adjust normally to his environment. In these days, it is doubtful that any child may reasonably be expected to succeed in life if he is denied the opportunity of an education. Such an opportunity, where the state has undertaken to provide it, is a right which must be made available to all on equal terms. ${ }^{2}$

Although the Supreme Court in its 1954 historic decision focused on the elimination of racial segregation in the public schools, it did recognize a right to equal educational opportunities for all. It seems rational and 
almost compelling to apply these words to retarded children since many of them may be "completely dependent on skills which only an education can provide." ${ }^{3}$ As Herr (1972) states, "As opposed to ordinary children, the severely retarded are not likely to achieve, informally or environmentally, even a minimal amount of development. Absent education, the retarded or handicapped citizen will be unable to function in society and may never develop the skills required even to care for himself. He is thus placed in jeopardy of institutionalization, loss of liberty, and even loss of life." ‘

In the United States today there are an estimated seven million children who have mental, physical, emotional, or learning handicaps. However, only forty percent or 2,800,000 of these children are receiving an education. ${ }^{5}$ Many children are excluded or suspended from school, transferred, reassigned, inappropriately placed, or denied special help. Many others have been placed on waiting lists for special education classes and, thus, have had their education indefinitely "postponed." Exclusion from school has been based on many grounds: that a child is emotionally disturbed, is mentally retarded or hyperactive, is a discipline problem, has some behavioral deficit (such as lacking language or not being toilet trained), or is unable to "pass" a standardized test. ${ }^{8}$ In addition, children in institutions often receive no (or minimal) education. If they have educational opportunities, these are often of poor quality. This all seems to add up to a denial of equal opportunity for education. Can this be done, and what recourse do these children and their parents or advocates have? To begin to discuss answers to these questions, it is first necessary to consider briefly some general constitutional and legal issues. Many of these issues have arisen in cases concerning the rights of institutionalized people to appropriate treatment and will be described within this context. Later, the relevance of these issues to the right to education will be explored.

\section{Constitutional and Legal Issues}

\section{Due Process}

The 14th Amendment states "nor shall any state deprive any person of life, liberty, or property without due process of law . . ." " A prohibition is similarly placed on the federal government by the 5 th Amendment which states that "no person shall . . . be deprived of life, liberty, or property without due process of law." ${ }^{8}$ These due process provisions have 
been interpreted to require that "fundamental fairness" be used by the government in any action affecting a person's liberty. For example, concerning involuntary deprivation of liberty, the Supreme Court has stated: "At the least, due process requires that the nature and duration of the commitment bear some reasonable relation to the purpose for which the individual is committed." "Thus, when a mentally retarded individual is involuntarily confined by a civil commitment which denies the full range of procedural safeguards made available to criminal defendants, and when this commitment can be for an indefinite term even though no criminal act has been committed, "fundamental fairness requires that treatment and not mere custody by the necessary quid pro quo for his loss of liberty." ${ }^{10}$ This may be labeled as substantive due process which "requires government action to be reasonable in purpose, method, and impact." "The requirement for "reasonable" action on the part of the government may also apply in cases where mentally retarded people are excluded from public education on the basis of vague and unjustifiable criteria.

Another kind of due process is procedural and requires that an individual be allowed a hearing, be notified of this hearing, be represented by counsel, be given the opportunity to present evidence, and be able to confront and cross-examine witnesses. ${ }^{12}$ Th is principle may apply in cases of involuntary commitment to institutions, in exclusion from educational opportunity, in transfers from one educational situation to another, and in placement in special education classes.

\section{Equal Protection of the Laws}

The 14th Amendment also states “. . . nor deny to any person within its jurisdiction the equal protection of the laws." ${ }^{13}$ This prohibits unfair discrimination against, or classification of, any individual or group of individuals. In right to treatment cases, for example, this means that persons can be classified as "mentally retarded," and subsequently deprived of their liberty, only if treatment is provided. If people are classified as mentally retarded and deprived of their freedom with no treatment, then unfair discrimination and a denial of equal protection has taken place because "they alone are picked out for 'preventive detention' while all other dangerous people who have not actually committed criminal acts are allowed to remain free." ${ }^{14}$ In addition, this can be applied to treatment received in one facility as compared to another: physical and financial resources and the personnel must be equal for the two. 
The equal protection provision has also been used in right to education cases. If the government undertakes to provide education at all, it must do so for everyone. It cannot discriminate against a mentally retarded individual unless there is a compelling state interest to do so. A "compelling state interest" requires a much stricter reason for action and must be distinguished from the usual requirement that a statute only be rationally related to a legitimate governmental objective.

\section{"Least Restrictive Environment” Principle}

This principle is based upon the premise that people should be free to live as they please unless they are harming others. The principle declares that when the government does have a legitimate goal to accomplish, it should do this by means that curtail individual freedom to the least extent possible while still securing the goal. ${ }^{15}$ The Supreme Court of the United States has made the following statement concerning judgment of governmental actions: "Even though the governmental purpose be legitimate and substantial, that purpose cannot be pursued by means that broadly stifle personal liberties when the end can be more narrowly achieved. The breadth of legislative abridgment must be viewed in the light of less drastic means of achieving the same basic purpose." ${ }^{18}$

There are several conditions where the principle of the "least restrictive alternative" may be applied. One is where the legislation establishing treatment or educational programs specifically outlines alternative methods, or leaves the court discretion in employing alternative methods. ${ }^{17}$ For example, if legislation establishing treatment programs for the mentally ill allows the court discretion in assigning a treatment program, the principle of the "least restrictive alternative" may suggest that a mentally ill person be treated at a local mental health clinic versus institutionalizing the person. Their rationale for using this principle is that commitment "entails an extraordinary deprivation of liberty" and that "such a drastic curtailment of the rights of citizens must be narrowly, even grudgingly, construed in order to avoid deprivation of liberty without due process of law." ${ }^{18}$ Similarly, the "least restrictive alternative" principle may apply in educational placement cases.

If legislation (statutes) does not specify that alteratives may be used, the Constitution may offer the necessary force. The United States Supreme Court and State Supreme Courts have ruled on several occasions, ${ }^{10}$ that state governments are compelled "to achieve clearly legitimate goals 
by schemes of regulation less constrictive of some important constitutionally protected interest than the scheme it was then using." ${ }^{20}$ The critical issue here is that to insist upon the court using the least restrictive alternative, the interest being affected by the state must be either: 1) a fundamental right or interest especially sensitive under the constitution (e.g., free speech) or 2) directed at groups discriminated against, where the criteria for grouping are regarded with special suspicion by the court (a suspect classification, e.g., race). Traditionally, three factors have been used to qualify a group as being a "suspect class": 1) an immutable or unalterable trait or disability over which the individual has no control, 2) a history of purposeful discrimination, and 3) a position of political powerlessness thus needing special judicial protection. ${ }^{21}$

If the interest being affected is not a fundamental right or directed at a group with suspect classification, and if the statutes do not outline alternative methods or allow the court discretion in accomplishing certain goals, then the state does not have to present as strict an argument for its actions and the principle of the "least restrictive alternative" might not be applied.

\section{Legal Tests in Litigation}

There are three types of tests which may be applied by the courts in litigation.

1. Strict Scrutiny. This is the strictest of the three tests. If the interest being affected is a fundamental right or directed at a group with suspect criteria, then the court applies this test. The defendant must show a "compelling interest" in his actions for the court to rule in favor of him.

The next two tests are used when the interest being affected is not a fundamental right or is not directed at a group with suspect criteria. These tests require a less strict standard of reason for action by the defendant. They are:

2. Means-Focused Test. This requires that the defendant show a careful consideration of the rationality of the action (e.g., legislation) to its purposes.

3. Rational Basis Test. This requires that the defendant show that the exclusion or discrimination of a group (e.g., the mentally retarded) serves a legitimate purpose. ${ }^{22}$ 
Issues in the Right to Education for the Retarded

Over the years many retarded children have been systematically excluded from appropriate educational opportunities. Is this legally justifiable? To answer this, the following questions will be considered:

Is education a fundamental right for all children, including the retarded?

Is exclusion of the retarded from schools a violation of equal protection of the laws?

Do retarded children have a right to due process before exclusion from the schools or placement in a special classroom?

Are retarded children entitled to an "appropriate" education?

Are there any procedural safeguards against the use of I.Q. tests, labeling and thus, the educational placement of retarded children?

Do retarded children in an institution have a right to education?

Can the principle of the "least restrictive means" be applied to education for retarded children?

What research has been done in the area of education for the retarded and how does it apply to the issues listed above?

Is Education a Fundamental Right for All Children, Including the Retarded?

A fundamental right is one that is guaranteed by the United States Constitution or the relevant state constitution. If a fundamental right is being affected, then the court presumably should apply a strict scrutiny test in arriving at a decision. Many state and lower federal courts and lawyers have "treated education as a fundamental interest requiring a strict scrutiny test," ${ }^{23}$ although none has claimed a federal constitutional right to education per $s e .{ }^{24}$ A recent Supreme Court case (San Antonio Independent School District $v$. Rodriquez, ${ }^{25}$ hereinafter referred to as "Rodriquez"), rejected the developing theory of education as a fundamental right and decided that education was not a fundamental right included "among the rights afforded explicit protection under our Federal Constitution." ${ }^{28}$ 
A state, however, through its constitution and laws, may guarantee education to all children. For example, the Kansas Constitution does provide for education..$^{27}$ In addition, special education is also provided for in a recently passed Kansas law. ${ }^{28}$ This special education is to be provided for "exceptional children" who are defined as:

. . persons who: (1) are school age, to be determined in accordance with rules and regulations which shall be adopted by the State Board and said school age may differ from the ages of children required to attend school under the provisions of K.S.A. 72-1111; and (2) differ in physical, mental, social, emotional or educational characteristics to the extent that special education services are necessary to enable them to progress toward the maximum of their abilities or capacities. ${ }^{29}$

The new bill states that:

The board of education of every school district shall provide special education services for all exceptional children in the school district and said special education services shall me standards and criterion set by the State Board. ${ }^{\text {so }}$

It, therefore, appears that as mandated by law all mentally retarded children in Kansas are to be provided with some type of special education. However, there are exceptions made in certain cases:

No school district shall be required to keep an exceptional child in regular instruction when the child cannot materially benefit from the work of the regular classroom, nor to provide such exceptional child with special education services for exceptional children when it is determined that the child can no longer materially benefit therefrom, or needs more specialized instruction. ${ }^{31}$

It should be noted that a child cannot be transferred to or from, or denied placement in special education services without first being afforded the right to a hearing. ${ }^{32}$

Thus, even though the Supreme Court has ruled that education is not a fundamental right guaranteed by the United States Constitution, a particular state constitution may guarantee this right to its residents. In states where the state constitution and laws do provide for education, and more specifically, for special education, each retarded child in that state may demand that education be provided as a right guaranteed by law. 
Is Exclusion of the Retarded from Schools a Violation of Equal Protection of the Laws?

1. Tests in litigation. Can a child who is capable of benefiting from any education be denied a public education? To answer this question under the equal protection clause, the appropriate standard for review must be determined. The three standards previously described are: the strict scrutiny standard, the means-focused approach, and the rational basis test. . $^{\text {s }}$

In order to use the strict scrutiny standard in this case, education must be a fundamental right or the mentally retarded must be considered a suspect class. Since Rodriquez ruled that education is not a fundamental right, this test can be used only if the mentally retarded are a suspect class. According to Richards and Williams, the mentally retarded do qualify as a suspect class because they meet the three necessary factors previously mentioned: (1) mental retardation is a disability over which the individual has no control; (2) the mentally retarded have a history of purposeful discrimination; and (3) the mentally retarded are in a position of political powerlessness. Thus, the mentally retarded seem to qualify as a suspect class, and a defendant (e.g., a school district) must show a compelling interest in order to exclude any mentally retarded person from public education. ${ }^{34}$

If a court, for some reason, did not use the strict scrutiny test, a meansfocused or rationale basis test could be applied. Both are concerned with the purpose and the action as it relates to the purpose. For example, the purpose of the Kansas educational system is to educate its citizens, i.e., "the legislature shall provide for intellectual, educational, vocational, and scientific improvement by establishing and maintaining public schools . . ." ${ }^{35}$ The question, then, is whether any action of excluding the mentally retarded is rationally related to Kansas' purpose of educating its citizens. It is estimated that $90 \%-95 \%$ of the people labeled as retarded could become partially or totally self-supporting. ${ }^{38}$ Since they are educable and could benefit from an education, ${ }^{37}$ excluding the mentally retarded seems wholly "arbitrary and irrational." $\mathbf{8 8}$

A state or school district may argue that there are not enough financial resources to educate the mentally retarded. However, to make this argument, they must show that not educating the retarded is less expensive than educating them. Wolfensburger (1969) estimated that with increasing institutional costs and increasing life spans, it may cost the public 
between $\$ 100,000$ and $\$ 350,000$ (over a lifetime of a child) to institutionalize a child. ${ }^{30}$ However, it should be noted that only a small proportion of retarded people are actually institutionalized. Even so, a large number of non-institutionalized, retarded people are cared for by the state in such community facilities as nursing homes, foster homes, boarding or group homes. Many other retarded people live at home and are cared for by their families. As will be discussed later, these people have the right to treatment equivalent to that given in an institution, although few receive it. Thus, the potential costs for treating retarded people living with their families may approximate the costs of institutionalizing them.

Considering all three tests, then, equal protection under the law "requires at the very least that all children be given access to the state system of public education." 40

2. Case law supporting equal protection. There are two landmark cases in the area of right to educate: Pennsylvania Association for Retarded Children $v$. Commonwealth of Pennsylvania (PARC), and Mills $v$. Board of Education of the District of Columbia.

The PARC case was decided on October 7, 1971. A three-judge federal court, following a consent agreement by the parties, ordered that all mentally retarded children in Pennsylvania "be given access to a free public program of education appropriate to their learning capacities." 4 The plaintiffs in this class action were the Pennsylvania Association for Retarded Children, fourteen named retarded children who were denied an appropriate education in Pennsylvania, and all other children similarly situated. The defendants were the Commonwealth of Pennsylvania, the Secretary of the Department of Education, the State Board of Education, the Secretary of the Department of Public Welfare, certain other school districts, their employees, officers, agents, and successors. ${ }^{\text {"s }}$

The Mills case was a class action suit. The plaintiffs were school-age children, who were residents of the District of Columbia, and "who had been denied placement in a publicly-supported educational program for substantial periods of time" "s because of "alleged mental, behavioral, physical, or emotional handicaps or deficiencies." " The plaintiffs sued on behalf of all children who were or would be similarly situated in the District of Columbia. They asked the court "to declare their rights and to stop defendants from excluding them from the District of Columbia Public Schools and/or denying them publicly supported education and from failing to provide them with immediate and adequate education and educational facilities in the public schools or alternate placement at public expense, and also to give them additional relief to help effect- 
uate the primary relief." ${ }^{4}$ The defendants were the Board of Education and its members, the mayor of Washington, D. C., the director of the Social Security Administration, and various administrators of the Washington, D. C. School System. The defendants acknowledged that they had a legal duty to provide education for all capable of benefiting from it in the District of Columbia; however, they stated that they lacked the necessary financial resources to do so.

Both the PARC and Mills cases found that total exclusion of handicapped children violates the equal protection clause of the Fourteenth and Fifth Amendments. The plaintiffs in both of these cases argued that a "strict scrutiny" test be used on the basis that education was a "fundamental interest" (this can no longer be used in cases because of the Supreme Court ruling in the Rodriquez case) and that handicapped children were classified using suspect criteria. The judges in the PARC case found that a denial of education violated the rational means test. The Mills case does not state what standard of review was used for its decision. $^{40}$ (It still may be argued that a strict scrutiny test could be used in either case because of the "suspect" category.) In the PARC case the courts went further in stating in its order that "all mentally retarded persons are capable of benefiting from a program of education and training . . ." ${ }^{47}$ Thus, even the severely and profoundly retarded should be provided an education. ${ }^{48}$ This has implications for state statutes that allow some children to be excluded from public education. Following the PARC ruling, these statutory provisions would be in violation of the equal protection clause.

Judge Waddy in the Mills case held that having insufficient funds does not excuse the defendants' duty to provide an education for the handicapped children. He made the following statement:

If sufficient funds are not available to finance all of the services and programs that are needed in the system then the available funds must be expended equitably in such a manner that no child is entirely excluded from a publicly supported education consistent with his needs and ability to benefit therefrom. ${ }^{40}$

Thus, both the Mills and PARC landmark cases support the theory that all retarded children should receive an education under the equal protection clause of the Fourteenth and Fifth Amendments. Several other cases relying on the equal protection clause are now pending in the courts. $^{\text {so }}$ 
Do Retarded Children Have a Right to Due Process Before Exclusion from the Schools or Placement in a Special Classroom?

1. Procedural due process. "Exclusionary practices may also be attacked as violative of procedural due process when no hearing is held before exclusion, regardless of the legality of the ground for exclusion." ${ }^{51}$ In both the PARC and Mills case (and several others) , ${ }^{52}$ the court ordered that due process requirements be fulfilled before any child be excluded or terminated from a program. These due process requirements include: a hearing, written notice of the hearing, counsel, opportunity to examine the child's school or medical records, opportunity to present evidence and confront and cross-examine witnesses, a right to independent medical, psychological, and educational evaluation of the child's capabilities, the right to a transcribed record of the hearing. Several cases considering this issue with the mentally retarded are pending in the courts. ${ }^{\text {ss }}$

2. Substantive due process. Regardless of the legality of the grounds for exclusion, exclusionary practices may be attacked as violative of substantive due process on the grounds that the criteria for exclusion in school laws, regulations, or policies are unduly vague or arbitrary, and unrelated to any legitimate reason for exclusion. ${ }^{\mathrm{st}}$ For example, the requirement that a child must be "ambulatory" or "toilet trained" might be unrelated to his ability to learn. The criteria used for exclusion must be written down, published, and made available to the parents. ${ }^{55}$ Similarly, in cases where only a limited number of children can be taken in a program, written standards and a fair procedure must be used for selection. ${ }^{58}$

Thus, it appear that no matter what a particular state statute reads, a parent has the right to insist that due process requirements be fulfilled before any child be excluded or terminated from a program. In addition, parents must be given specific written standards that tell what criteria are used for exclusion. Nonetheless, if a child is excluded (independent of how specific the criteria), he or she is entitled to procedural due process hich includes a hearing.

\section{Are Retarded Children Entitled to an "Appropriate" Education?}

The Supreme Court recognized in Brown $v$. Board of Education that a child had a right to "equal educational opportunity." However, the court 
neglected to specify what was required in order to meet "equal educational opportunity." Rodriquez requires that at least an adequate minimum be provided for each child in every school district. ${ }^{57}$ The court in PARC required that every retarded person between the ages of six and twenty-one be given "access to a free public program of education and training appropriate to his learning capacities." ${ }^{\circ 8}$ In the Mills case the court ordered that plaintiffs be provided "with a publicly supported education suited to their plaintiffs' needs . . ." ${ }^{\text {s8 }}$ It seems evident that the courts believe that children must be provided an equal education opportunity that is appropriate to their needs. Just providing special education for a child is not enough; the education must be appropriate to a child's capabilities and needs.

The issue then becomes how one defines "appropriate." Richards and Williams suggest that equal and appropriate education would provide the means to enable each child to learn as much as he is able according to the "widely varying capabilities . . ." of each child. However, they admit that exactly what a state must provide for each child is yet undetermined..$^{\circ 0}$

Although the exact specifications of an "appropriate" education have yet to be made, parents of retarded children have a right to a due process advisory hearing before a child is initially placed in a particular classroom, before he is denied placement, or transferred from one classroom or program to another. ${ }^{01}$ This can also provide the child and his parents the opportunity to have an input into the decision as to what type of educational program is appropriate to the child's individual needs. Due process requires that a school defend its placement of a child in terms of the appropriateness of the program. ${ }^{.2}$

An article by Weintraub and Abeson (1972) cites an interesting proposal by Gallagher, ${ }^{\text {os }}$ that would increase the accountability of public education. Gallagher suggests that placement procedures require a formal contract between the school and parents. The contract would specify the following: "obligations of all parties, the educational objectives to be achieved, criteria for assessing their achievement, a timetable for evaluation, and procedures for renegotiating the contract." "* Under this proposal, then, schools would have to demonstrate some type of behavioral change (e.g., reading skills learned or improved) instead of merely providing a program. When public schools cannot demonstrate that they are teaching a retarded child (i.e., in terms of behavioral skills learned), the courts have held that the public school is responsible for paying tuition to a private school where the child does make progress in learning. ${ }^{\circ 5}$ 
Thus, while the courts have ruled that children should receive an education appropriate to their needs, "appropriate" has yet to be defined. Perhaps one way of defining an "appropriate" education for each child is to specify what skills and behaviors a child needs to learn. If the education teaches these specific skills and behaviors, then it can be called "appropriate."

Are There any Procedural Safeguards Against the Use of I.Q. Tests, Labeling, and Thus, the Educational Placement of Retarded Children?

Often children have been given I.Q. tests and then placed in "appropriate" classrooms. Garrison and Hammill (1971) state that "when the I.Q. is used as the single criterion for identification, gross errors in placement are possible." ${ }^{\circ 8}$ For many children I.Q. tests may not accurately reflect their learning ability. Ross, DeYoung, and Cohen (1971) suggest three reasons why: (1) I.Q. tests are generally standardized on the performance of white, middle-class students; (2) they are heavily verbal; and (3) they contain questions that are more easily answered by white, middle-class students. Thus, these tests may "discriminate against children of racial and cultural minorities and are therefore in violation of the equal protection clause of the 14th Amendment . . ." or

Because of the above reasons, several successful suits have challenged the use of testing instruments (e.g., I.Q. tests) to place children in special education classes Diana 7 . State Board of Education ${ }^{88}$ involved Spanish speaking children who claimed they had been improperly placed in classes for the retarded on the basis of inaccurate tests. A consent decree was agreed upon which required that non-English speaking children be tested in both their primary language and in English and that the tests must not depend on such things as vocabulary, general information, or any other unfair verbal question. Further, it was specified in the consent decree that all Chinese and Mexican-American children in classes for the retarded were to be retested. A similar consent decree was obtained in Guadalupe Org. $v$. Tempe Elementary School District. ${ }^{\theta \theta}$

In another landmark case, Hobson $v$. Hansen, ${ }^{70}$ the court ruled that the "tracking" system of educational placement used in Washington, D. C. public schools was illegal. The plaintiffs used the aforementioned argument that the testing procedures used for placement were prejudicial. On the basis of these test scores, children were placed in honors, general, or special (educable mentally retarded) curriculum classes. The judge 
found that there were disproportionate numbers of black children in the special classes and attributed this to cultural bias of the test. In addition, there were infrequent retests, so a student could easily become locked into a certain track. The court, using the equal protection clause, held that the tracking system and its testing procedures "irrationally separated students on the basis of race and socioeconomic background and thereby violated their right to an equal educational opportunity." ${ }^{71}$

The court reached a similar decision in Larry $v$. Riles ${ }^{72}$ stating that I.Q. tests were "suspect" and the school must show a rational relationship between the testing apparatus and the ability to learn. When the children in this case were retested by personnel who rephrased the questions, the plaintiffs were not classified as retarded. The fact that a disproportionate number of children of a particular race are in special classes does not necessarily establish lack of equal protection, but this does put a burden on the state to show that the tests used for placement are not discriminatory. ${ }^{73}$ Using these same arguments about I.Q. tests and subsequent placing, suits have been brought against school districts seeking money damages as a remedy against unfair placement practices. $^{74}$

An issue related to placement of retarded children is that of classifying the handicapped by labels, such as "trainable mentally retarded." Several authors in the field feel such labeling can cause serious problems. Weintraub and Abeson ${ }^{76}$ feel that such labels may produce four major problems:

1. Children classified as educable or trainable mentally retarded may become the victims of significant stigma. The PARC court spoke on this issue:

Experts agree that it is primarily the school which imposes the mentally retarded label and concomitant stigmatization upon children either initially or later on through a change in educational assignment. ${ }^{70}$

2. Once a child is assigned a label, those who work with him often have stereotyped expectations of his behavior. This is often referred to as the "self-fulfilling prophecy." Kenneth Clark expresses this in a good example:

If a child scores low on an intelligence test because he cannot read and then is not taught to read because he has a low test score, then such a child is being imprisoned in an iron circle and becomes the victim of an educational self-fulfilling prophecy. ${ }^{77}$ 
3. Public and private agencies which offer special services often determine the population they will serve on the basis of a pre-assigned label.

4. Children with labels, such as "mentally retarded" or "handicapped," may be placed in a special education program independent of whether or not it is needed. This gets back to the use of having a label placed on a child because of the results of an I.Q. test.

The Supreme Court ruled under the due process clause in a Wisconsin case $^{\pi x}$ that a hearing must be provided before a label or stigma can be publicly given to a person. In educational litigation the argument could be used that labeling a person "mentally retarded" in the school system is a public stigma and must require a notice before it can be done. However, past educational litigation has set a much stronger precedent for arguing against the use of I.Q. tests as the sole criterion for the educational placement of a child, especially if the test is not administered in his native language. Some states (e.g., Kansas) will be requiring a hearing before a child can be placed in a special education class. At this hearing, school personnel will need to specify the reasons for placement of a child. This provides a protection against the use of vague or unfair criteria (e.g., I.Q. tests) for school placement.

\section{Do Retarded Children in an Institution Have a Right to Education?}

Thus far we have been talking about the right to education for children who live in the community. What about children who reside in institutions? Many state statutes provide for the education of children who reside in institutions. An example is one of the Kansas statutes which states the objective of one of the state institutions for the mentally retarded.

The object of Parsons State Hospital and Training Center shall be to examine, treat, educate, train, and rehabilitate the persons admitted and retained so as to make such persons more comfortable, happy, and better fitted to care for and support themselves. To this end, the secretary shall provide such examination, treatment, education (including academic and vocational), training and rehabilitation facilities as he shall deem necessary and advisable. ${ }^{79}$

The objective of other Kansas institutions for the mentally retarded are similar. Thus, relying on state statutes, one may find a guarantee for the right to education for children residing in institutions. 
Courts have also ruled that children in institutions have a right to education. In Wyatt $v$. Stickney a recent right-to-treatment case involving three Alabama institutions (including Partlow, an institution for the mentally retarded), the court ruled that:

Residents shall have a right to receive suitable educational services regardless of chronological age, degree of retardation or accompanying disabilities or handicaps . . . School age residents shall be provided with a full and suitable educational program and such programs shall meet prescribed minimal standards. ${ }^{80}$

These standards were: ${ }^{81}$

1. Class Size

2. Length of school year in months

3. Minimum length of school day in hours
Mild

12

$9-10$

6
Severe/

Moderate

9

$9-10$

6
Profound

6

$11-12$

Although these standards are a step in the right direction, they do not specify that any behavioral change (i.e., skill learned or improved) take place. We have the same problem here as was discussed before in public education.

If a state, through its statutes, provides for education of children in institutions, the questions arise of which residents in the institution should be in educational programs and what standards should be set for education in these institutions? Relying on the ruling in Wyatt, all children, regardless of their degree of retardation, should be receiving an education. Again equal protection of the law could be used as an argument for this.

Concerning the standards set for education, if it could be shown that the institutions were not educating the residents (in other words, few people were learning new skills or ones which would allow them to better care for themselves), then one could argue that the institution should provide programs that do teach these skills or the children should be placed (and, thus, funds appropriated) in programs or facilities that do accomplish these goals. Also, if educational facilities in an institution are inferior to those in the community, a denial of equal protection could be argued. 
Can the Principle of the "Least Restrictive Means" Be Applied to Education for Retarded Children?

In cases where the courts have recognized the right to education for all children, some have also ordered that the least restrictive program of education be used. The court, in the PARC case, ordered that:

among the alternative programs of education and training required by statute to be available, placement in a regular public school class is preferable to placement in a special public school class, and placement in a special public school class is preferable to placement in any other type of program of education. ${ }^{82}$

The court in the Wyatt case, when speaking of habilitation, also spoke of the least restrictive alternative. Habilitation, as defined by the court, refers to "programs of formal, structural education and treatment." ${ }^{\text {s }}$ The court stated: "Residents shall have a right to the least restrictive conditions necessary to achieve the purposes of habilitation." ${ }^{84}$ It therefore appears that the state must show at least a rational reason why a child should be educated in an institution as opposed to a special class in a public school as opposed to a regular classroom.

One approach that has been taken in order to provide the most "appropriate" and the "least restrictive" type of education is that of the "Cascade System" shown below. ${ }^{85}$

Number of Children

Regular Classroom

I. Regular classroom with specialist consultation

II. Regular classroom with itinerant teachers

III. Regular classroom plus a resource room

Part Time Special Class

Full Time Special Class

Special Day School

Residential School

Hospital 
This continuum of educational service model allows a child to be placed in the setting appropriate to his needs. The critical feature of this model, though, is that it allows a child to move in order to have "the maximum" opportunity to obtain and participate in a normal educational experience." so

Another interesting idea is that of providing a financial incentive for local school districts to serve all mentally retarded children (instead of relying on segregated alternatives) and mainstreaming them (i.e., getting them back into regular classes) ${ }^{87}$ This might be done in the following way: first, financial incentives could be given to a school district for taking a child from an institution and placing him in some type of program in the public schools. Incentives could also be given to a school district for taking emotionally disturbed, behavior problem children, and the mentally retarded from the community and placing them in programs in the public schools. Some states do allow for additional state monies to be given to a school district for special classes or special teachers to assist children in the regular classroom. In addition, all state assistance (including that for "normal" children) could be made contingent on the school district providing services for every child. This incentive procedure might initially be used just to get children back into the public schools, but we must be careful that our incentive program does not just reinforce the establishment of special classes and, thus, segregation of the mentally handicapped. Therefore, incentives (e.g., time off or extra pay) should be provided for teachers who are willing to take these emotionally disturbed, behavior problem, or mentally retarded children back into the regular classroom for at least a short period of time (i.e., a couple of hours a day), and eventually for the entire school day.

Finally, incentives could be provided for teachers who show the development of important skills in the children they teach. This is important for all children in school, but is especially crucial for the mentally retarded. Often they need much more input than a normal child needs in order to learn a specific skill, whether it be tying his or her shoes or learning to read. Too often, educational programs exist for the mentally retarded that merely try to "make them happy." Although this is important, it is also important to teach them. One might argue that this is essentially what teachers are paid to do and, therefore, they should not receive anything extra (even extra time off) for doing it. Even though this is what teachers are supposed to do, the fact remains that often it does not happen; often retarded children stay in the same class for years without progressing in terms of learning new skills. To get teachers "to teach," a 
minimal base pay could be given to the teacher upon being hired. Increments in the pay level could be contracted for by the teacher demonstrating behavioral changes in his or her children.

What Research Has Done in the Area of Education for the Retarded and How Does it Apply to the Issues Listed Above?

Abeson (1972) reports that research findings have indicated that early childhood education is essential for all children, especially the handicapped. Thus, he recommends that states lower their minimum entrance age of school to birth. ${ }^{88}$ Likewise, he feels that since many handicapped youths may need prolonged education in order to successfully adapt to the "normal" world, states should extend the maximum age limit to 21 years or higher. ${ }^{80}$

Cegelka and Tyler (1970) wrote an excellent review article on whether educable mentally retarded children should receive their education in a special or regular classroom. ${ }^{00}$ They first discussed studies which looked at academic performance. Most of the studies matched children in a special class with children in a regular class on the dimensions of CA, IQ, and sex. The most sophisticated studies also matched the subjects on such dimensions as socioeconomic community ratings, history of school attendance, foreign language spoken in the home, and reading achievement. The results were split between the studies: some showed that there were no differences in academic performance, as measured by achievement tests, between children placed in a special education class as opposed to comparable children placed in a regular class; the other results demonstrated that children placed in regular classes had higher performance on achievement tests than did children placed in special education classes. Few studies demonstrated higher performance achieved by children left in a special classroom.

Cegelka and Tyler also reviewed the research data on the social and emotional adjustment of educable mentally retarded children placed in special classes as opposed to regular classes. Results again seemed to be ambiguous. Some studies reported that special class placement led to poorer self-concept among these children, while others reported the opposite. Cegelka and Tyler concluded that much more research needs to be done in this area.

Postschool adjustment of the educable mentally retarded has also been 
researched. Two widely quoted studies were also reviewed by Cegelka and Tyler. One found that the only difference between postschool adjustment of students from special as opposed to regular classes was that employer ratings were more favorable for the special class groups as versus those for the regular class. ${ }^{01}$ The other study also indicated an advantage for persons who had atteended a special class during their school years. The important difference in this study seemed to be in the greater frequency of employment of the persons in the special class group. ${ }^{92}$

The lack of consistent differences between children in special and regular classes is difficult to interpret. On one hand it it possible that many children are initially misplaced in special classes, thus accounting for the lack of differences on test and other performance measures. Such a conclusion is suggested by the results of a study by Garrison and Hammill. ${ }^{\text {ss }}$ On the other hand, it is possible that special classes take children with behavioral and intellectual deficits and make them approximate other "normal" children with the same C.A. and I.Q. Cegelka and Tyler suggest some controls and changes that might be used in future studies of this type. Content taught in classes should be controlled for, since achievement tests may be measuring what is taught in a regular class but not in a special class. In addition, the teaching procedures and curricular should be controlled. Because students are equal in I.Q., one cannot assume that they are equal in other characteristics; these should be controlled for. Often children are assigned to special education classes not merely on the basis of test scores, but also because of various behavioral characteristics: they are disruptive and aggressive in class, hyperactive, and lack instructional control. To the extent that these behaviors do differentiate between children assigned to regular and special education classes, and to the extent that they are predictive of future difficulties in school and in other situations, comparisons based on the outcomes of children matched only on test scores may be inappropriate. What seems to be needed is a study which probably will never be done: random assignment of children with equivalent learning and behavioral deficits and excesses to regular and special education classes to see if there are differential outcomes.

Nonetheless, the past research seems to have important implications. At the present time, there seems to be no conclusive evidence that children assigned to special education classes benefit more or less than children assigned to regular classes. If retarded children can be educated as well in regular classrooms, it seems economically more efficient to do so. Also, it would seem preferred in terms of the "least restrictive" method and in reducing labels attached by special classrooms. 
Conclusion

Although the courts have not regarded education as a fundamental right afforded explicit protection under the United States Constitution, many states, through their constitutions and laws, have guaranteed education to all children. In these states, retarded children can demand that education be provided to them as a right and that the educational opportunities provided be ones which benefit them and be appropriate to their needs. Before children are placed in special classrooms, they have the right to both procedural and substantive due process which involves, among other things, the opportunity for a hearing, the opportunity to present evidence and the examination of the criteria for placement in the special classroom. These rights apply equally for retarded children living in the community as well as those residing in institutions. Further, the "least restrictive alternative" applies. This implies that the educational goals should be accomplished in a way which limits an individual's freedom and liberty the least. In practice, this may mean an increasing emphasis on the use of educational programs in the community where a retarded person lives rather than in institutions. Finally, the right to education implies that criteria exist for evaluating whether education is effective and adequate. It is proposed that the effectiveness of education in producing specified desirable behavioral changes be one of the primary criteria used in an evaluation.

\section{Footnotes}

1. Preparation of this paper was supported partially by PHS Training Grant HD00183 and partially by Program Grant HD-00870, each from the National Institute of Child Health and Human Development.

2. Brown $v$. Board of Education, 347 U.S. 483, 493 (1954) .

3. Mental Health Law Project. Basic Rights of the Mentally Handicapped. Washington, D. C.: Mental Health Law Project, 1973, 40.

4. Herr, S. Retarded children and the law: enforcing the constitutional rights of the mentally retarded. In Symposium: the legal rights of the mentally retarded. Syracuse Law Review, 23, 1972, 1003.

5. Weintraub, F. J. and A. R. Abeson. Appropriate education for all handicapped children: a growing issue. In Symposium: the legal rights of the mentally retarded. Syracuse Law Review, 23, 1972, 1037.

6. Mental Health Law Project. See note 3 supra at p. 41.

7. United States Constitution, Fourteenth Amendment, Section 1.

8. United States Constitution, Fifth Amendment.

9. Jackson $v$. Indiana, 406 U.S. 715, 738 (1972) .

10. Mental Health Law Project. See note 3 supra at p. 15.

11. Id. at p. 38.

12. Id.

13. See note 7 supra.

14. Mental Health Law Project. See note 3 supra at p. 16. 
15. Chambers, David. Right to the least restrictive alternative setting for treatment. In B. J. Ennis and P. R. Friedman (Eds.) Legal Rights of the Mentally Handicapped (vol. 2). New York: Practising Law Institute, 1974, 993.

16. Shelton $v$. Tucker, 364 U.S. 479, 488 (1960) .

17. Lake $v$. Cameron, 364 F.2d 657 (D. C. Cir. 1966) ; Covington $v$. Harris, 419 F.2d 617 (D. C. Cir. 1969) .

18. Covington $v$. Harris, 419 F.2d 617, 622-25 (D. C. Cir. 1969) .

19. Dean Milk Co. $v$. City of Madison, 340 U.S. 349, 354-56 (1951) ; Dunn v. Blumstein, 405 U.S. 330, 347-49 (1972) ; Shelton $v$. Tucker, 364 U.S. 479, 488 (1960) ; Police Department of the City of Chicago $v$. Mosley, 408 U.S. 92, 100-02 (1972); Carrington $v$. Rash, 380 U.S. 89, 95-97 (1965) .

20. Chambers, D. See note 15 supra at p. 995.

21. Richards, S. K. and L. G. Williams. Toward a legal theory of the right to education of the mentally retarded. Ohio State Law Journal, 34, 1973568.

22. Id. at 568 .

23. Id. at p. 564 .

24. Wald, P. M. The right to education. In B. J. Ennis and P. R. Friendman (Eds.) Legal Rights of the Mentally Handicapped (vol. 2). New York: Practising Law Institute, 1974, 835.

25. San Antonio Independent School District $v$. Rodriquez, 93 S. Ct. 1278 (1973) .

26. Id. at p. 1297.

27. Kansas Constitution, Article 6, Section 1.

28. Kansas House Bill No. 1672, 1974.

29. Kansas House Bill No. 1672, Section 2 (f) , 1974.

30. Kansas House Bill No. 1672, Section 6 (a), 1974.

31. Kansas House Bill No. 1672, Section 7, 1974.

32. Kansas House Bill No. 1672, Section 13 (a), 1974.

33. Richards, S. K. and L. G. Williams. See note 21 supra at p. 568.

34. Id.

35. Kansas Constitution, Article 6, Section 1.

36. Richards, S. K. and L. G. Williams. See note 21 supra at p. 559.

37. Haggerty, Kane, and Udall. An essay on the legal rights of the mentally retarded. Family Law Quarterly, 6, 1972, 65.

38. Richards, S. K. and L. G. Williams. See note 21 supra at p. 569.

39. Wolfensberger, W. A new approach to decision-making in human management services. In President's Committee on Mental Retardation Monograph, Changing Patterns in Residential Service for the Mentally Retarded. Washington, D. C.: U. S. Government Printing Office, 1969, 379.

40. Richards, S. K. and L. G. Williams. See note 21 supra at p. 569.

41. Mental Health Law Project. See note 3 supra at p. 42.

42. Friedman, P. R. Mental Retardation and the Law, April, 1973, 26.

43. Id. at p. 29.

44. Mental Health Law Project. See note 3 supra at p. 45.

45. Id. at p. 46.

46. Wald, P. M. See note 24 supra at p. 836.

47. Pennsylvania Association for Retarded Children $v$. Commonwealth of Pennsylvania (PARC) , 343 F. Supp. 279 (1972) .

48. Murdock, C. W. Civil rights of the mentally retarded - some critical issues. Family Law Quarterly, 8, 1973, 49.

49. Mills $v$. Board of Education of the District of Columbia, 348 F. Supp. 866 (1972) .

50. Lori Case et al. $v$. State of California, Department of Education, et al., Civil Action No. 101679 (Cal. Superior Court, Riverside County) ; Colorado Association for Retarded Children $v$. The State of Colorado (U. S. District Court, Colorado) ; Florida Association for Retarded Childen et al. $v$. State Board of Education, Civil Action No. 730250-CIV-NCR (U. S. District Court, Southern District of Florida); Maryland Association for Retarded Children, Leonard Bramble, et al. $v$. State of Maryland et at., Civil Action No. 720733-K (U. S. District Court, Maryland); Reid $v$. Board of Education of the City of New York, Civil Action No. 71-1380 (U. S. District Court, Southern District, New York); Crystal Rene Hamilton $v$. Dr. J. Iverson Riddle, Superintendent of Western Carolina Center, Civil Action No. 72-86 (Charlotee Division, U. S. District Court, Western District, North 
Carolina) ; North Carolina Association for Retarded Children, Inc., James Auten Moore, et al., $v$. The State of North Carolina Board of Public Education (E.D.N.C., Raleigh Division); North Dakota Association for Retarded Children $v$. Peterson (U. S. District Court, North Dakota, Southwestern Division); Mindy Linda Panitch et al., $v$. State of Wisconsin, Civil Action No. 72-L-461 (U. S. District Court, Wisconsin) ; Wilcox, et al., v. Carter, et al., Civil Action No. 73-41 (U. S. District Court, Middle District, Florida) ; California Association for Retarded Children $v$. State Board of Education, No. 237277 (Superior Court, Sacramento County) .

51. Wald, P. M. See note 24 supra at p. 837.

52. LeBanks $v$. Spears, Civil Action No. 71-2897 (E.D. La. 1973) ; Knight $v$. Board of Education 48 F.R.D. 108 (E.D.N.Y., 1969) ; cf. Wisconsin $v$. Constantineau, 400 U.S. 433 (1971) ; Vought v. VanBuren Public Schools, 306 F. Supp. 1388 (E.D. Mich. 1969) ; Williams v. Dade County School Board, 441 F.2d 229 (5th Cir. 1971) .

53. See note 50 supra.

54. Cf. Sullivan $v$. Houston Independent School District, 307 F. Supp. 1328 (S.D. Tex. 1969); Alexander $v$. Thompson, 313 F. Supp. 1389 (D. Cal. 1970);-Crassen $v$. Fats, 309 F. Supp. 114 (D. Conn. 1970) .

55. Wald, P. M. See note 24 supra at p. 838.

56. Cf. Holmes $v$. N.Y.C. Housing Authority, 398 F.2d 262, 265 (2nd Cir. 1968).

57. Richards, S. K. and L. G. Williams. See note 21 supra at p. 573.

58. PARC, 343 F. Supp. 279, 258-66 (1972) (underlining added) .

59. Mills $v$. Board of Education, 348 F. Supp. 866 (1972) .

60. Richards, S. K. and L. G. Williams. See note 21 supra at p. 572.

61. LeBanks $v$. Spears, Civil Action No. 71-2897 (E.D. La. 1973) ; PARC, 343 F. Supp. 279 (1972) ; Mills $v$. Board of Education, 348 F. Supp. 866 (1972) .

62. Weintraub, F. J. and A. R. Abeson. See note 5 supra at p. 1057.

63. Gallagher. The special education contract for mildly handicapped children. Exceptional Childen, 38, 1972, 527-35, within note 5 supra at p. 1057.

64. Weintraub, F. J. and A. R. Abeson. See note 5 supra at p. 1057.

65. In Re Held, Nos. H-271 and H-10-71 (N.Y. Fam. Ct. 1971).

66. Garrison, M. and D. D. Hammill. Who are the retarded? Exceptional Children, 38, $1971,5$.

67. Ross, S. L., H. G. DeYoung, and J. S. Cohen. Confrontation: special education placement and the law. Exceptional Children, 38, 1971, 5.

68. Diana $v$. State Board of Education, C-70, 37 R.F.D. (N.D. Cal. 1970) .

69. Guadalupe Org. $v$. Tempe Elementary School District, Civ. No. 71-435 PHX, Ct. No. 6312D D. Arizona (1972).

70. Hobson $v$. Hansen, 269 F. Supp. 401 (D.D.C. 1967) .

71. Ross, S. L., H. G. DeYoung, and J. S. Cohen. See note 67 supra at p. 7.

72. Larry P. v. Riles, 343 F. Supp. 1306 (N.D. Cal. 1972) .

73. Wald, P. M. See note 24 supra at p. 847.

74. Covarrubias $v$. San Diego Unıfied School District, No. 70-394-T (S.D. Cal. 1971) ; Stewart $v$. Phillips, C. A. No. 70-1199-F (D. Mass. 1971).

75. Weintraub, F. J. and A. R. Abeson. See note 5 supra at pp. 1038-39.

76. PARC, 343 F. Supp. at p. 295.

77. Clark, K. Educational stimulation of racially disadvantaged children. Education in Depressed Areas, 142, 150 (A. H. Passow, ed., 1963) quoted from Richards, S. K. and L. G. Williams. See note 21 supra at p. 579.

78. Wisconsin $v$. Constantineau, 39 U.S.L.W. 4128 (1971) .

79. K.S.A. 76-1409.

80. Wyatt $v$. Stickney, 344 F. Supp. at p. 397.

81. Id.

82. PARC, 343 F. Supp. at p. 312.

83. Wyatt $v$. Stickney, 344 F. Supp. at p. 387.

84. Id. at p. 396.

85. Reynolds. A framework for considering some issues in special education. Exceptional Children, 28, 1962, 367-70.

86. Weintraub, F. J. and A. R. Abeson. See note 5 supra at p. 1040.

87. Sage, D. D., J. P. Gaughan, and R. G. Rice. The financial issue in education of the handicapped. Fourth in a Series: "Notes from the Center." New York: Center on Human Policy, 1973. 
88. State-Federal Information Clearinghouse for Exceptional Children. Preschool Programs for the Education of Handicapped Children - Summary Report. Arlington, Va. SFICEC, 1972, as cited in Abeson, A. Movement and momentum: Government and the education of handicapped children. Exceptional Children, 39, 1972, 63.

89. Abeson, A. Movement and momentum: Government and the education of handicapped children. Exceptional Children, 39, 1972, 64.

90. Cegelka, W. J. and J. L. Tyler. The efficacy of special class placement for the mentally retarded in proper perspective. American Institute for Mental Studies, Training School Bulletin, 67, 1970.

91. Carriker, W. R. A comparison of postschool adjustments of regular and special class retarded individuals served in Lincoln and Omaha, Nebraska, public schools. Unpublished dissertation, University of Nebraska, 1957, as cited in Cegelka, W. J. and J. L. Tyler. See note 90 supra at p. 58.

92. Porter, R. B. and T. C. Milazzo. A comparison of mentally retarded adults who attended a special class with those who attended regular school classes. Exceptional Children, 24, 1958, 410-412, 420, as cited in Cegelka, W. J. and J. L. Tyler. See note 90 supra at p. 58.

93. Garrison, M. and D. D. Hammill. See note 66 supra at pp. 13-20. 